Cronfa - Swansea University Open Access Repository

This is an author produced version of a paper published in :

Journal of Breath Research

Cronfa URL for this paper:

http://cronfa.swan.ac.uk/Record/cronfa31718

\title{
Paper:
}

Peel, A., Crossman-Barnes, C., Tang, J., Fowler, S., Davies, G., Wilson, A. \& Loke, Y. (2017). Biomarkers in adult asthma: a systematic review of 8-isoprostane in exhaled breath condensate. Journal of Breath Research http://dx.doi.org/10.1088/1752-7163/aa5a8a

This article is brought to you by Swansea University. Any person downloading material is agreeing to abide by the terms of the repository licence. Authors are personally responsible for adhering to publisher restrictions or conditions. When uploading content they are required to comply with their publisher agreement and the SHERPA RoMEO database to judge whether or not it is copyright safe to add this version of the paper to this repository. http://www.swansea.ac.uk/iss/researchsupport/cronfa-support/ 


\section{Biomarkers in Adult Asthma: a Systematic Review of 8-Isoprostane in Exhaled Breath Condensate}

Authors: Adam M Peel ${ }^{1}$, Christina-Jane Crossman-Barnes ${ }^{1}$, Jonathan Tang ${ }^{1}$, Stephen J Fowler $^{2}$, Gwyneth A Davies ${ }^{3}$, Andrew M Wilson ${ }^{1}$, Yoon K Loke ${ }^{1}$.

Author affiliation: ${ }^{1}$ Norwich Medical School, University of East Anglia, Norwich Research Park, Norwich, NR4 7TJ. '2Education and Research Centre, University Hospital South Manchester, Wythenshawe, Manchester, M23 9LT. ${ }^{3}$ Asthma \& Allergy Group, Swansea University, Singleton Park, Swansea, SA2 8PP.

Conflicts of interest: none Corresponding author: Adam M Peel; a.peel@uea.ac.uk

Support: The research is funded by the University of East Anglia, supported by the Asthma UK Centre for Applied Research, and being undertaken as part of a PhD programme (AMP).

\section{Abstract}

Objectives: We aimed to assess the evidence for the use of 8-isoprostane in exhaled breath condensate $(E B C)$ as a biomarker in adult asthma. Design: A systematic review and meta-analysis of EBC 8-isoprostane. Methods: We searched a number of online databases (including PubMed, Embase and Scopus) in January 2016. We included studies of adult non-smokers with EBC collection and asthma diagnosis conducted according to recognised guidelines. We aimed to pool data using random effects meta-analysis and assess heterogeneity using $\mathrm{I}^{2}$. Results: We included twenty studies, the findings from which were inconsistent. Seven studies $(n=329)$ reported 8 -isoprostane levels in asthma to be significantly higher than that of control groups, whilst six studies $(n=403)$ did not. Only four studies were appropriate for inclusion in a random effects meta-analysis of mean difference. This found a statistically significant between-groups difference of $22 \mathrm{pg} / \mathrm{ml}$. Confidence in the result is limited by the small number of studies and by substantial statistical heterogeneity $\left(\mathrm{I}^{2}=94\right)$. Conclusion: The clinical value of EBC 8-isoprostane as a quantitative assessment of oxidative stress in asthma remains unclear due to variability in results and methodological heterogeneity. It is essential to develop a robust and standardised methodology if the use of EBC 8-isoprostane in asthma is to be properly evaluated. 


\section{Introduction}

With the ascendance of personalised medicine and recognition of the heterogeneity within asthma there has been a drive to develop non-invasive measures of disease activity. Collecting and analysing the condensate from exhaled breath (EBC) is one such method, studied since the early 1980's (1). Several different commercial devices are available and this methodology has been adopted in a number of studies looking at an ever growing number of potential biomarkers.

Oxidative stress is thought to play an important role in asthma, as both a causative factor and a result of inflammation $(2,3)$. It occurs where there is a failure of homeostasis - due either to an excess of reactive oxygen species (ROS) or to a lack of antioxidants - and can cause cellular damage, proinflammatory mediator release, mucous secretion, remodelling of extracellular matrix, smooth muscle contraction and bronchoconstriction (3-5).

The reaction of ROS with other molecules is so rapid that their direct measurement is difficult; however, end products of ROS 'attack' are more stable and may be useful as surrogate markers for oxidative stress. 8-isoprostane is one such marker; specific to oxidative stress, stable, and measurable in EBC (6-8). Paediatric studies of EBC 8isoprostane have been the subject of a systematic review (9) which found the majority of studies reported a significant association between 8-isoprostane and asthma, however, as biomarker thresholds vary with age (10), there is a need to review the adult literature. We aimed to assess the evidence regarding the efficacy of EBC 8-isoprostane as a biomarker - its ability to identify disease, disease severity and response to treatment. We chose to conduct a comprehensive systematic review because this enables us to view the evidence as whole, and to identify common themes as well as inconsistencies that may only become apparent through evaluation of the entire dataset.

\section{Methods}

\section{Study design}

The study protocol was registered with and is available from the International Prospective Register of Systematic Reviews (PROSPERO) (registration number CRD42016027312). The primary objective of the review was to assess the ability of 8-isoprostane to identify and distinguish between a) those with asthma and healthy controls b) levels of asthma severity, and c) response to treatment. A secondary objective was to determine possible thresholds appropriate to a diagnosis of asthma or classification of severity.

\section{Search Strategy}

A search strategy was developed using terms relating to asthma, exhaled breath condensate and 8-isoprostane (see appendix table 1). 
Two reviewers (AMP \& CJCB) screened titles and abstracts for inclusion, resolving discrepancies through discussion with a third reviewer (YKL). The screening and selection process is described in a PRISMA flow chart (see figure 1).

Fig. 1 - PRISMA Diagram
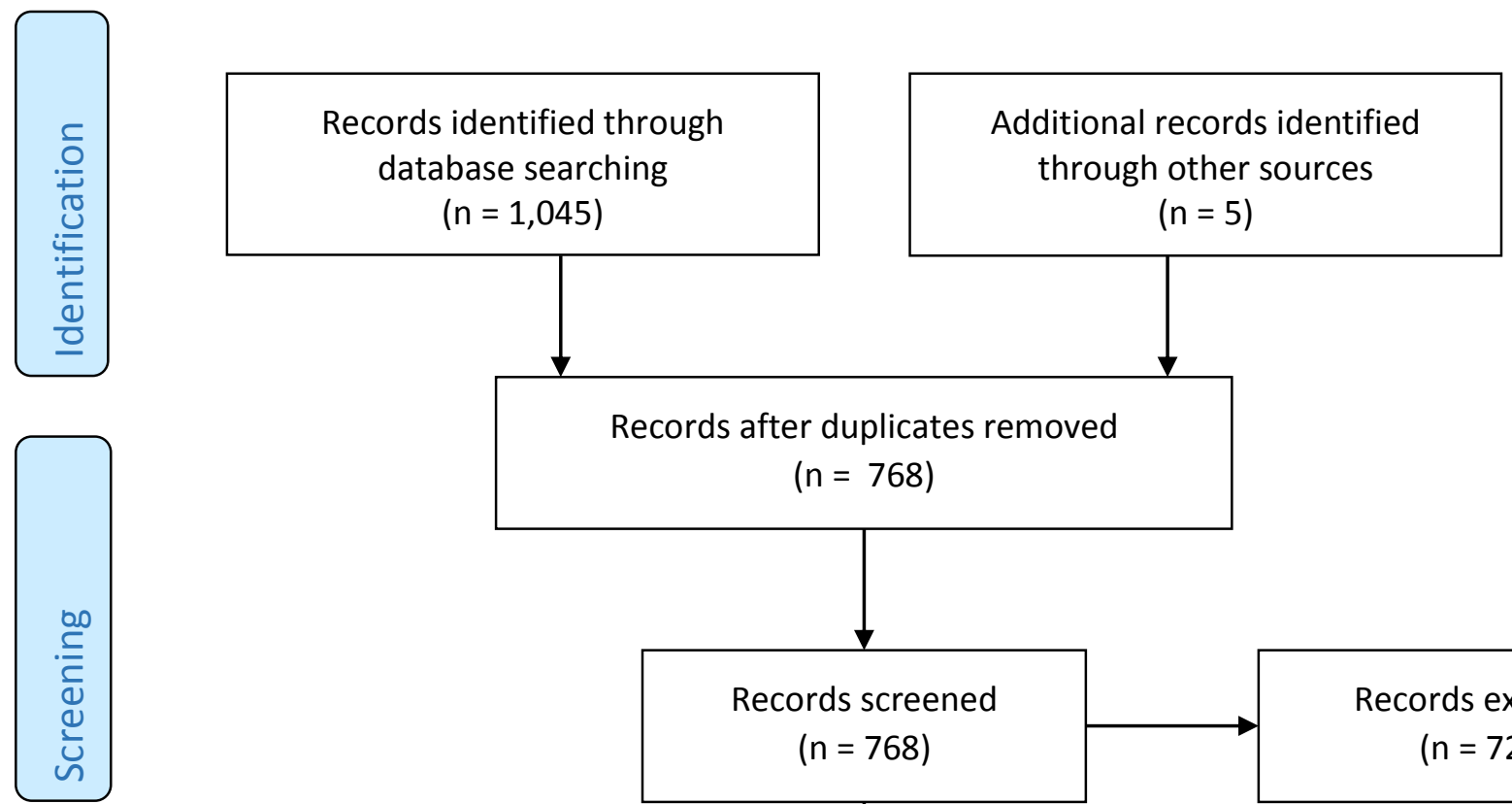

Records after duplicates removed

$$
(n=768)
$$

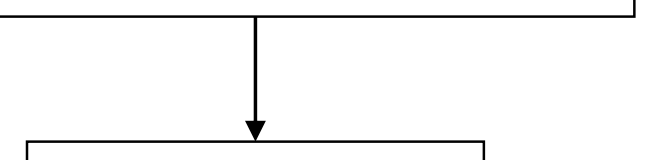

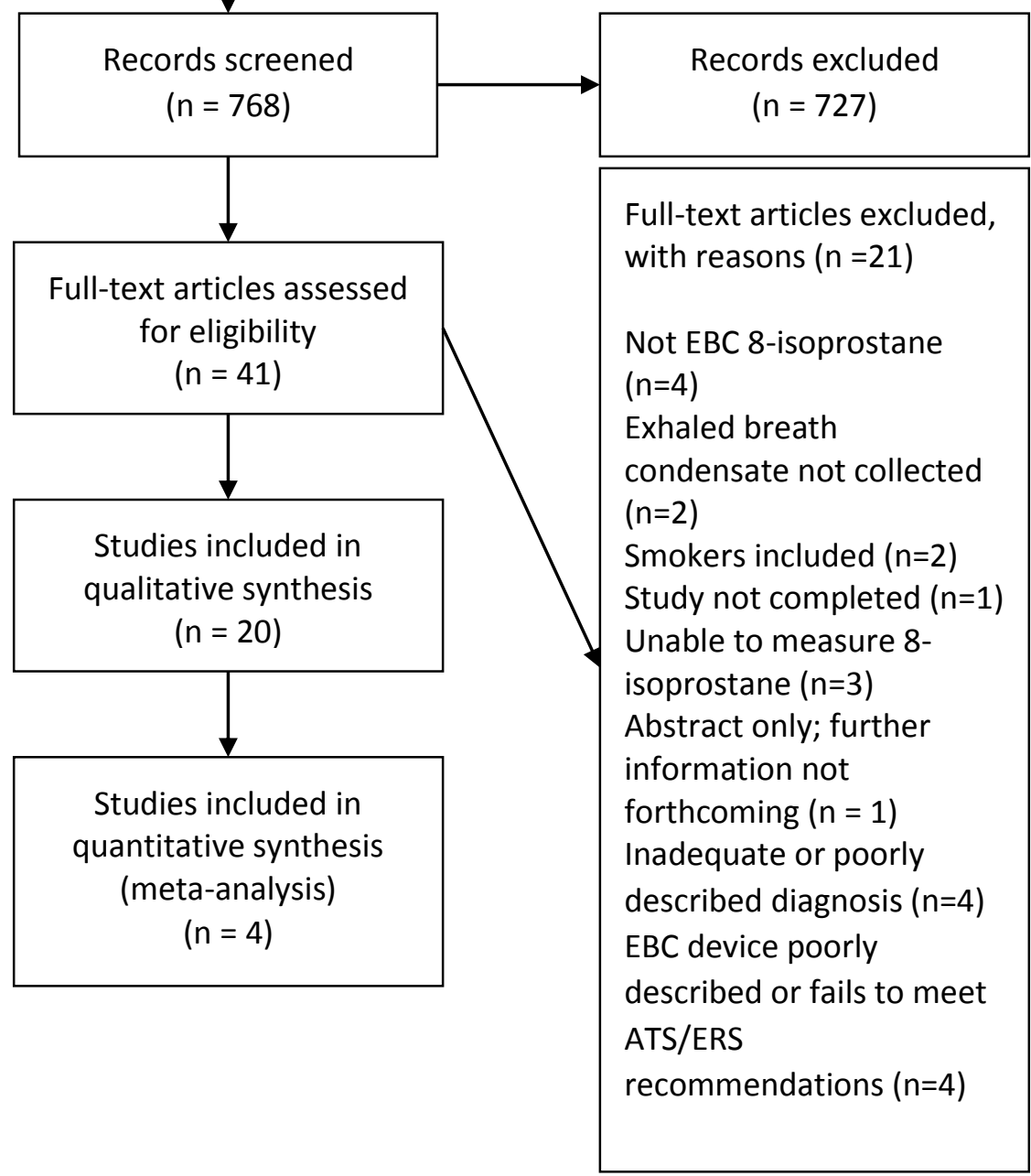




\section{Eligibility criteria}

Inclusion / exclusion criteria are described in table 1 below.

Table 1 - Inclusion \& Exclusion Criteria

\begin{tabular}{ll}
\hline Inclusion criteria & Exclusion criteria \\
\hline Abstract in English & Review articles \\
Primary data & Studies including paediatric patients \\
Quantitative data & Studies of occupational asthma \\
Diagnosis of asthma according to & Studies of current smokers \\
recognised guidelines & In vitro studies \\
EBC 8-isoprostane measured & Use of a custom EBC device with insufficient \\
Human subjects & description or which fails to meet ATS/ERS \\
Adult participants (aged 18+) & guideline recommendations (11). \\
& Studies published as comment / letters will have \\
& a request for further information made; they will \\
& be excluded if further detail is not forthcoming. \\
\hline
\end{tabular}

Studies were excluded if the EBC collection device failed to meet ATS/ERS construction guidelines (12) (or was described insufficiently to determine this), or if the method of asthma diagnosis failed to meet recognised guidelines or was incompletely described. An exception to this was the use of nose-clips; although this was recommended, the guidelines state that there were no data underpinning this recommendation. A study by Vass et al (13) published since the guidelines found no significant difference between samples collected with or without nose-clips (although 8-isoprostane was not one of the mediators studied).

During the initial screening process several conference abstracts were found. On contacting the authors it was confirmed that the results had not been published more fully elsewhere but insufficient information was forthcoming to determine suitability for inclusion. In order to avoid selective dissemination bias an analysis of these papers was included. 


\section{Data Extraction \& Quality Assessment}

Data extraction and quality assessment was conducted by two reviewers independently (AMP and CJCB). Data were extracted directly into SPSS (14); papers were assessed for quality and risk of bias (15); and the overall strength of evidence was assessed $(16,17)$. Discrepancies between the two reviewers were resolved through discussion with a third (YKL).

\section{Statistical methods}

We aimed to produce a quantitative synthesis using methods appropriate to the data extracted and to assess statistical heterogeneity using the $\mathrm{I}^{2}$ statistic. We used Open-Meta Analyst to conduct a random effects meta-analysis of mean difference (between asthma and control groups) for those studies reporting continuous data with a mean and standard deviation (SD). Where the SD was not reported we calculated it from confidence intervals or standard error (except where data had been transformed). In studies with multiple arms we combined data. We were not able to include papers which presented their results as a median and range.

\section{Results}

We identified 1,045 papers through the database search and a further five through reference searches (see PRISMA diagram, appendix figure 1). This was reduced to 768 on removal of duplicates. Title and abstract screening resulted in 41 papers which was reduced to 20 after screening full texts. Study characteristics are summarised in table 2 . 
Table 2. Study characteristics and results

\begin{tabular}{|c|c|c|c|c|c|c|}
\hline Author & $\begin{array}{l}\text { Publication } \\
\text { type }\end{array}$ & Country & $\mathbf{N}=$ & EBC device & $\begin{array}{c}\text { Method } \\
\text { of } \\
\text { analysis }\end{array}$ & Study focus \\
\hline Battaglia et al (2005) & Journal & Netherlands & 31 & EcoScreen & ELISA & $\begin{array}{l}\text { Small airway } \\
\text { function }\end{array}$ \\
\hline Brussino et al (2010) & Journal & Italy & 32 & RTube & ELISA & $\begin{array}{l}\text { Allergen } \\
\text { challenge }\end{array}$ \\
\hline Carpagnano et al (2006) & Journal & Italy & 26 & EcoScreen & $\begin{array}{l}\text { ELISA + } \\
\text { GC-MS }\end{array}$ & GORD \\
\hline Fritscher et al (2012) & Journal & Canada & 67 & RTube & $\begin{array}{l}\text { LC- } \\
\text { MSMS }\end{array}$ & COPD \& asthma \\
\hline Gratziou et al (2008) & Journal & Greece & 28 & EcoScreen & ELISA & $\begin{array}{l}\text { Seasonal allergic } \\
\text { rhinitis \& asthma }\end{array}$ \\
\hline $\begin{array}{l}\text { Head \& Mickleborough } \\
\text { (2013) }\end{array}$ & Journal & USA & 7 & EcoScreen & LC-MS & Supplements \\
\hline Komakula et al (2007) & Journal & USA & 114 & RTube & ELISA & $\mathrm{BMI}$ \\
\hline Kostikas et al (2002) & Journal & Greece & 50 & $\begin{array}{l}\text { Custom } \\
\text { device }\end{array}$ & ELISA & $\mathrm{pH}$ \\
\hline Mastalerz et al (2011) & Journal & Poland & 21 & EcoScreen & GC-MS & Aspirin sensitivity \\
\hline Mastalerz et al (2015) & Journal & Poland & 53 & EcoScreen & GC-MS & Aspirin sensitivity \\
\hline $\begin{array}{l}\text { Mickleborough et al } \\
(2013)\end{array}$ & Journal & USA & 20 & EcoScreen & ELISA & Supplements \\
\hline Piotrowski et al (2011) & Journal & Poland & 52 & EcoScreen & ELISA & Asthma severity \\
\hline
\end{tabular}




\begin{tabular}{|c|c|c|c|c|c|c|}
\hline Samitas et al (2009) & Journal & Greece & 62 & EcoScreen & ELISA & Asthma severity \\
\hline Shimizu et al (2007) & Journal & Japan & 62 & EcoScreen & ELISA & GORD \\
\hline Sood et al (2013) & Journal & USA & 14 & RTube & ELISA & Allergen \\
\hline Zhao et al (2008) & Journal & Japan & 64 & EcoScreen & ELISA & GORD \\
\hline
\end{tabular}

Potentially eligible studies (conference abstracts)

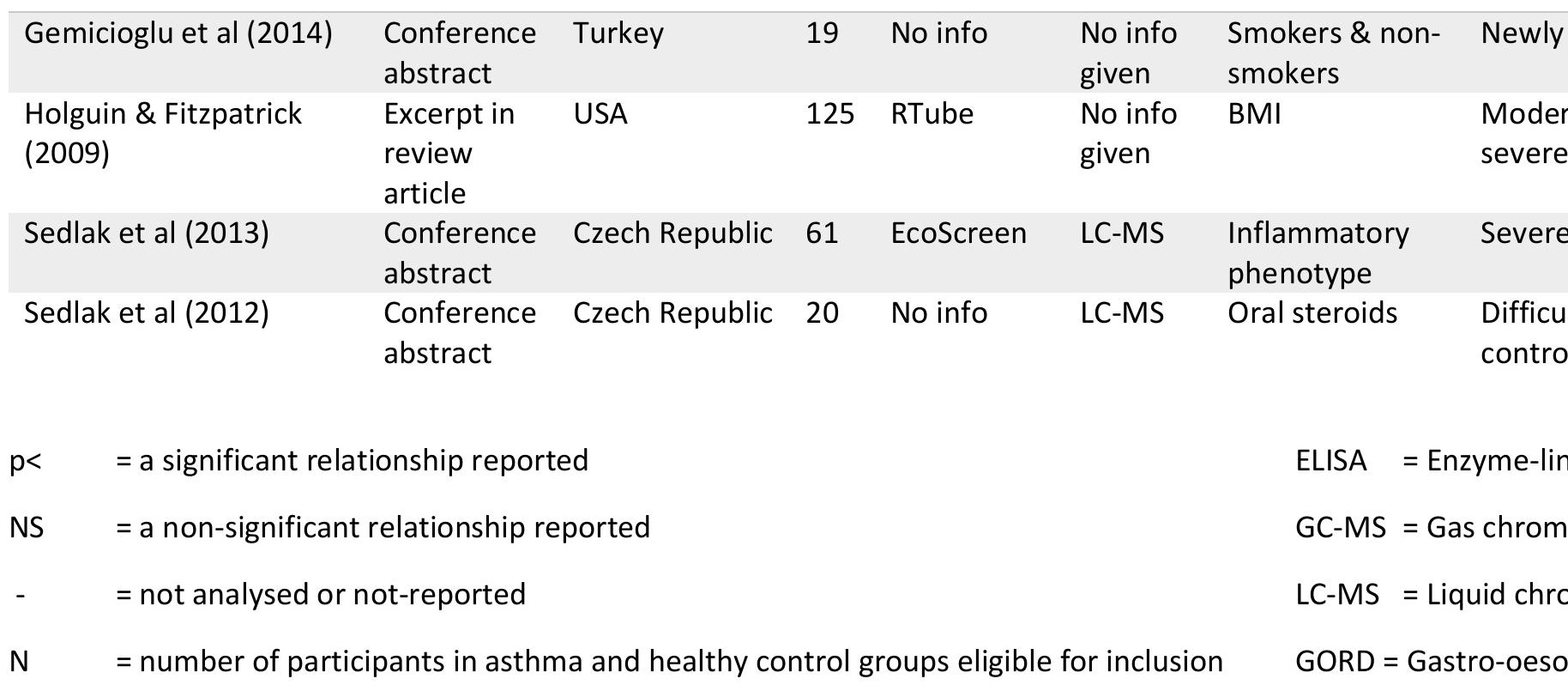




\section{QUALITY ASSESSMENT}

Results of the Quadas-2 quality assessment can be found in appendix table 3. It was not possible to assess the risk of bias arising from patient selection methods or from the conduction of the index test (EBC collection); in all but one paper description of patient sampling and/or recruitment methods was absent, and in only one paper was it clear whether the laboratory analysis of EBC was conducted by someone blinded to the participants' asthma status.

The time between reference and index standards was not clearly stated in five of the papers. The larger the interval the greater the risk of a change in condition between the two assessments and potential misclassification of asthma severity; we deemed asthma assessment within 1 week of EBC collection to be acceptable. Participant drop-out occurred in very few studies.

\section{Variability: Pre-analytical}

One study (Samitas et al (18)) coated the condenser surface of their EBC collection device in Tween-20 (a non-ionic surfactant) to reduce eicosanoid adherence. They report 8isoprostane concentrations which are towards the higher end of results within this review. The extent to which this was due to the use of Tween-20 is unclear; Sood et al (19) examined this method and found no significant difference in 8-isoprostane between samples collected with or without Tween.

Three studies (Battaglia et al (20), Fritscher et al (21) and Sood et al (19)) undertook or cited 8-isoprostane recovery rates obtained from spiking tests; all were over $90 \%$. Sood et al found that concentrating their samples by lyophilisation had no effect on recovery rates, whereas Battaglia et al found lower rates when they used an immunoaffinity sorbent and lyophilisation.

Kostikas et al (22) cooled their condensing surface to minus $10^{\circ} \mathrm{C}$ whereas other studies used minus $20^{\circ} \mathrm{C}$. We included this study as it does not contravene ATS/ERS recommendations and evidence on the effect of temperature on EBC 8-isoprostane collection is conflicting (23-25).

Not mentioned in the ATS/ERS guidelines but specified by Cayman in their enzyme-linked immunosorbent assay (ELISA) information (26) is the use of an anti-oxidant - butylated hydroxytoluene $(\mathrm{BHT})$ - for EBC samples which are being frozen and stored for later analysis. This is to prevent further (in vitro) oxidative formation of 8-isoprostane. The majority of studies using ELISA kits stored their samples for later analysis but none reported the use of BHT. 
Relatively few studies reported the length of time samples were stored for but Samitas et al evaluated the stability of 8 -isoprostane at minus $80^{\circ} \mathrm{C}$ and found no significant difference in samples tested at one, four and eight weeks (although an upward trend could be noted).

\section{Variability: Analytical}

For their ELISA, Cayman cited a sensitivity of $3 \mathrm{pg} / \mathrm{ml}$ and inter-assay variation rates of $10-24 \%$ however this validation was not undertaken in EBC. Sood et al (19) found the intra-assay CV in EBC to be $37.7 \%$ compared to $6 \%$ in buffer diluent. They concluded that interference from the EBC matrix was possible; the extent to which this might be a confounder in other studies is unclear as Sood et al's analysis was conducted on a lyophilised, concentrated EBC sample. The majority of studies in this review cite intraassay and inter-assay $\mathrm{CV}<10 \%$.

Several studies utilised mass spectrometry techniques as their method of analysis - GCMS and LC-MS/MS methods offer improved sensitivity and selectivity over immunoassays, hence they are often regarded as the superior method for measurement of isoprostanes (27-29). Fritscher et al (21) report the limit of detection with LC-MS to be $0.05-0.1 \mathrm{pg}$; while Mastalerz et al (30) report that of GC-MS to be between 0.17 and $0.89 \mathrm{pg} / \mathrm{ml}$. The results found by studies using mass-spectrometry frequently fell below the lower detection limit of immunoassays. Two papers compared the results produced by ELISA methods with a) GC-MS (Carpagnano et al) and b) radioimmunoassay (Sood et al). Sood et al report discordance between methods while Carpagnano do not.

The absence of prime certified standard reference materials (SRM) produced by accredited bodies (such as NIST) for the production of calibration curves is a further source of potential inaccuracy and inter-laboratory variation.

\section{Grade Assessment}

A GRADE assessment was completed (using GradePro GDT (31)) for the twelve studies reporting on both asthma and control groups (see appendix table 4). The strength of the evidence pertaining to the differentiation of disease status was judged to be very low due to the inconsistency and imprecision of results.

\section{Summary}

For the majority of included papers there are no concerns over applicability to the review question but the risk of bias in the studies is largely unclear and there are unresolved methodological questions. Overall assessment of the evidence grade is very low. 


\section{QUANTITATIVE SYNTHESIS}

\section{Prediction of asthma attack or treatment response}

There were no studies examining the strength of association between 8-isoprostane concentration and frequency of asthma attack, nor studies examining the ability of 8isoprostane to predict the risk of attack or response to treatment.

\section{Differentiation of disease status}

There was a large degree of clinical heterogeneity; studies examined different asthma phenotypes and severities, and utilised different interventions (including provocation tests and treatments). Given the broad study question we were addressing we considered the studies sufficiently homogenous for meta-analysis despite these differences.

Using Open Meta Analyst (32) we conducted a random effects meta-analysis of mean difference between groups (see figure 2 ). The estimated mean difference was +21.62 $\mathrm{pg} / \mathrm{ml}$ in those with asthma (standard error 5.21). The $\mathrm{p}$-value of $<0.001$ suggests statistical significance, and the lower bound of the meta-analytical point estimate $11.4 \mathrm{pg} / \mathrm{ml}$ - is above the detection limit for the ELISA $(2.8$ to $7 \mathrm{pg} / \mathrm{ml})$. However, the $\mathrm{I}^{2}$ test result - 94 - suggests a considerable degree of statistical heterogeneity, and the estimated mean difference $(21.62 \mathrm{pg} / \mathrm{ml})$ should be viewed in light of the overall range of averages for EBC 8 -isoprostane which varied from $0.25 \mathrm{pg} / \mathrm{ml}$ to $78.10 \mathrm{pg} / \mathrm{ml}$. 
Figure 2 - Random Effects Meta-Analysis of Mean Between-Group Difference (asthma vs controls)

\section{Studies}

Kostikas 2002

Samitas 2008

Shimizu 2007

Zhao $2008_{1}$

Overall $\left(I^{\wedge} 2=94.46 \%, P<0.001\right) \quad 21.619 \quad(11.412,31.825)$
Estimate (95\% C.I.)

$13.000 \quad(7.482,18.518)$

$42.900(34.457,51.343)$

$21.100(16.015,26.185)$

$12.000(9.639,14.361)$

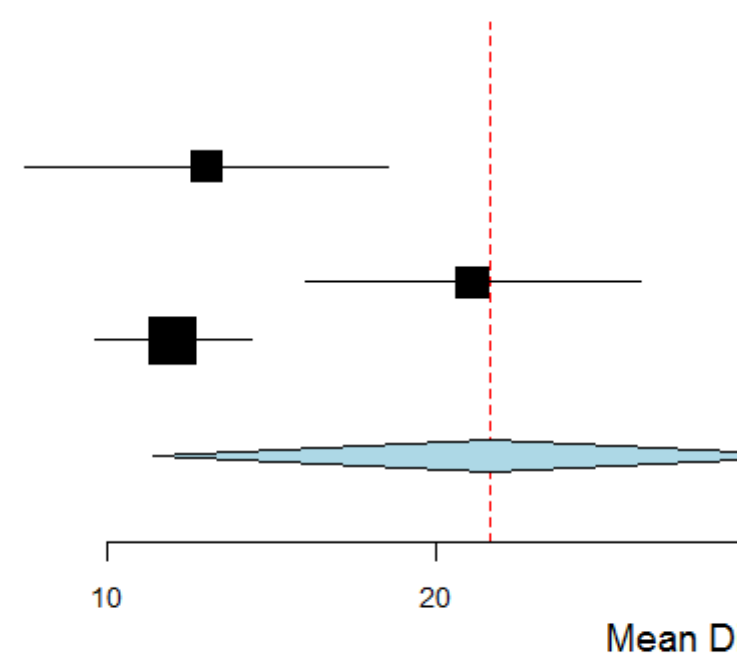

Study weights: Kostikas 25\%, Samitas 23\%, Shimizu 25\%, Zhao 27\%.

1 Zhao et al (33) cited a median and IQR but also gave a mean. There was little difference between the mean and median calculated SD from the IQR and included this study in the meta-analysis. 


\section{QUALITATIVE SYNTHESIS}

Ten papers $(n=419)$ reported average 8 -isoprostane levels to be higher in asthma than in healthy controls, while five papers $(n=389)$ reported averages to be the same or higher in controls.

Of the ten studies reporting higher concentrations in asthma, only seven $(n=329)$ reported the difference to be statistically significant. However, of the three which were excluded, two $(22,34)$ simply omitted to report the significance level, while the third study - Sood et al (19) - was not powered to detect a between-group difference in 8-isoprostane concentration.

With the exclusion of conference abstracts, five papers $(n=248)$ report a significant difference, and five papers $(n=278)$ report either no significant difference or higher concentrations amongst controls. All papers scored similarly in their quality assessment. A full list of results can be found in appendix table 5 . 
Results from those papers reporting a median (figure 3) and those reporting a mean (figure 4) are displayed below. Even when looking only at those studies reporting a significant between-groups difference, there is a considerable overlap of results between studies - the range of values for controls in one study being similar to those for asthma in another. This degree of statistical heterogeneity precludes the determination of threshold values.

Figure 3 - Median 8-isoprostane and Range: Asthma groups versus controls

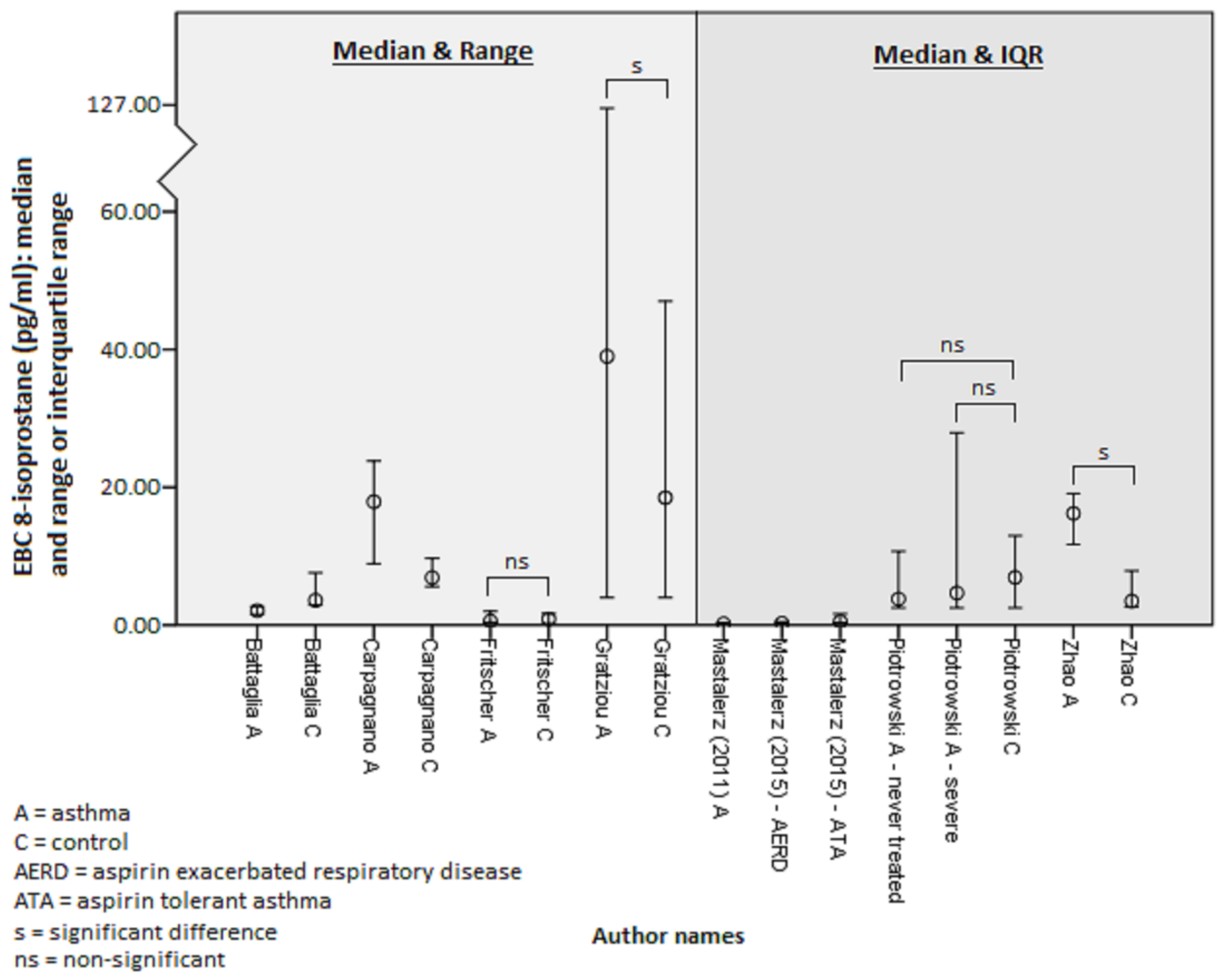


Figure 4 - Mean 8-isoprostane and Standard Deviation: Asthma groups versus controls

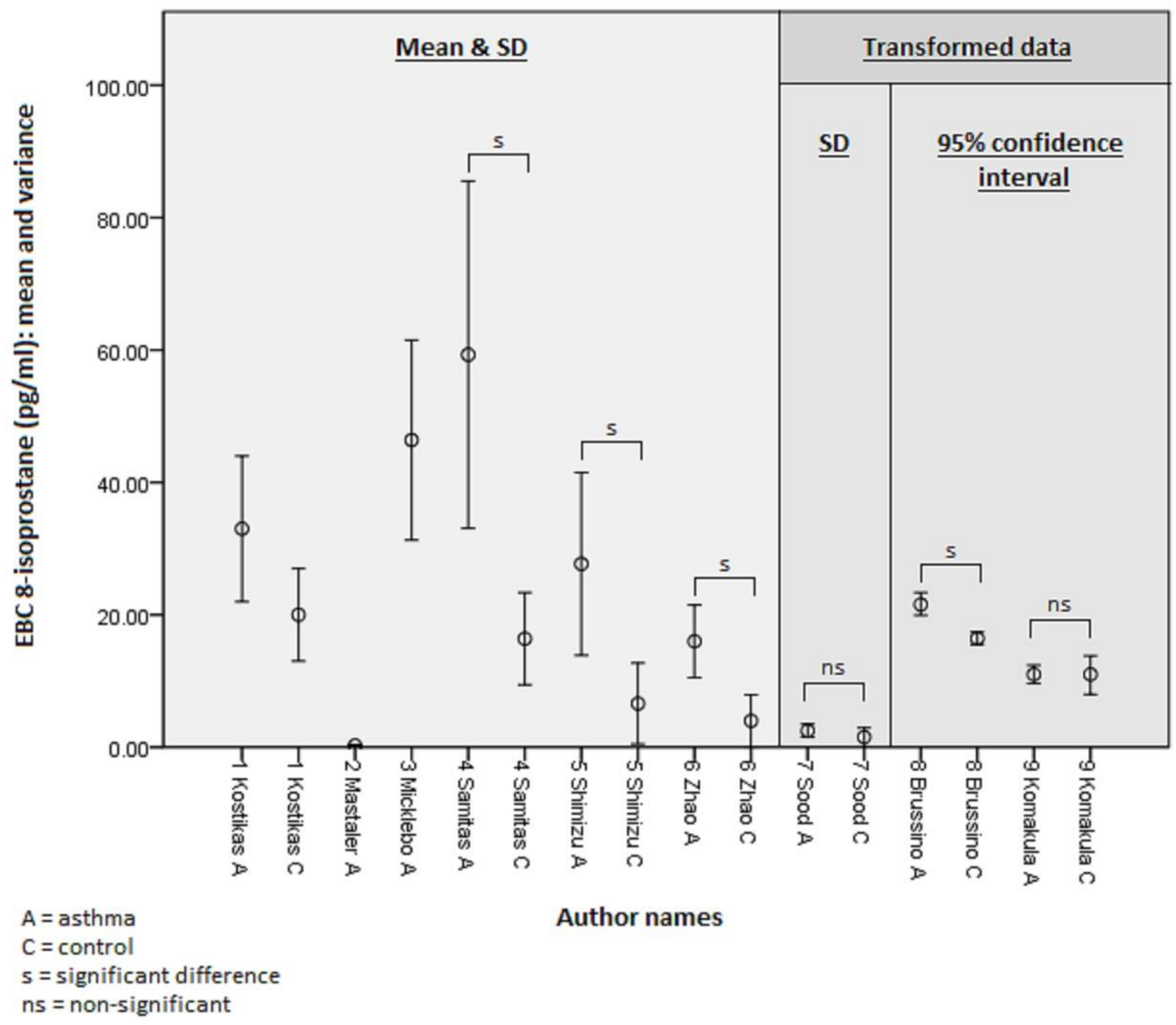

There was a large degree of overlap in 8-isoprostane concentration between severities of asthma. This may be attributable to between-study methodological differences, however, three studies $(18,21,35)$ made within-study comparisons of severity. Samitas et al (18) report a significant difference between the severe and milder asthma groups, whereas Piotrowski et al (35) report a small, non-significant difference $(0.87 \mathrm{pg} / \mathrm{ml})$. Kostikas et al (36) report a difference of $15 \mathrm{pg} / \mathrm{ml}$ but do not comment on its statistical significance.

Both Brussino et al (37) and Sood et al (19) investigated the effect of allergen challenge on EBC 8-isoprostane concentration. Brussino et al reported a statistically significant increase while Sood et al reported no such change. 
Gratziou (38) studied patients with seasonal allergic rhinitis and concurrent asthma, reporting significantly higher levels of 8 -isoprostane during pollen season, and a significant decrease after treatment with nasal corticosteroids. Mastalerz et al $(30,39)$ conducted a pair of studies in which patients with aspirin intolerant asthma (AIA) or aspirin exacerbated respiratory disease (AERD) were subjected to an aspirin challenge; they found no significant difference in 8-isoprostane after challenge.

Baseline measures of pulmonary function (spirometry) were commonly reported in order to characterise study populations; their relation to EBC 8-isoprostane was less commonly examined. Eight studies conducted such an analysis, of which only two reported a significant (negative) correlation. Similarly, baseline blood eosinophil count was reported by five papers but analysed in relation to 8 -isoprostane by only one (reporting no correlation). FeNO was measured by six studies; four assessed the degree of correlation with EBC 8-isoprostane only one of which yielded a statistically significant (positive) association. Two papers undertook sputum analysis; one reported on the relationship with EBC 8-isoprostane - no significant association was found.

\section{SUBGROUP ANALYSIS}

Methodological heterogeneity has been suggested as one of the factors inhibiting clinical use of EBC (12). Those papers included in the meta-analysis all used ELISA as their method of analysis but represent a mixture of asthma severities and EBC collection devices. A subgroup analysis of EBC collection and analytical methods was used as a means of exploring this heterogeneity.

Five of the seven studies using the EcoScreen reported a positive difference between asthma and control groups; four were statistically significant, the fifth was not reported upon. Of the four studies using the RTube, two reported a positive difference between groups of which one was statistically significant. The condensing surface of the RTube is polypropylene while on the EcoScreen it is teflon. Several papers have looked at the possible impact of device and condensing surface upon EBC results (23-25, 40-44). Czebe et al (24) compared the RTube and EcoScreen and concluded that both temperature and condenser surface had an impact on biomarker levels. Soyer et al (23) found similar results although neither study examined 8-isoprostane. Rosias et al (25) did study 8-isoprostane and concluded that condenser surface did have an effect but that there was no difference between polypropylene and teflon. Moreover they concluded that temperature difference between the two did not appear to have a significant effect on 8-isoprostane collection. Based on current studies of methodology we cannot be certain that choice of device explains any of the heterogeneity in the results. 
Regarding analytic method, if the outlier generated by the inclusion of conference abstracts (Sedlak et al (45)) is excluded, the results from mass spectrometry exhibit a smaller range and are considerably lower than the majority of results from ELISA. However, Carpagnano et al (34) - the only study to confirm their ELISA results using gas chromatograph-mass spectrometry - report no discrepancy between the two measures; this is in line with previous studies (46). That analytical method is responsible for a degree of heterogeneity in the results is plausible but cannot be stated with certainty.

The inclusion of papers studying mild or intermittent asthma - in which there may be little or no oxidative stress - might explain the lack of consistently observed difference between asthma and control groups.

A sub-group analysis comparing moderate-to-severe asthma with controls was conducted to explore this possibility. Results were inconclusive; of the eight included papers $(18,22$, $35,45,47-50$ ) five reported a between-groups difference (four of which were statistically significant) while three reported no difference (see appendix table 6).

\section{Discussion}

This review highlights a lack of comparability between studies, as well as evidence gaps which create difficulties in determining 8-isoprostane thresholds for diagnosis or severity classification of asthma. The clinical value of EBC 8-isoprostane as a quantitative assessment of oxidative stress in asthma remains unclear due to variability in results and inadequate standardization.

The previously published paediatric review (9) reported more consistent findings - five of the six identified studies found a significant difference between asthma and healthy control groups. However, the studies exhibited a similarly large degree of variance in their results (ranging between $4.2-56.4 \mathrm{pg} / \mathrm{ml}$ for asthma and $2.6-34.2 \mathrm{pg} / \mathrm{ml}$ for control groups).

The ATS / ERS taskforce of 2005 (11) was set-up to address variability in EBC results and lack of standardisation in methods. They suggested two likely contributors to variability varying $E B C$ dilution levels and biomarkers being at the lower end of assay sensitivity. That there exists a large degree of variance in 8-isoprostane concentration levels even where studies have used the same EBC collection method would support these assertions.

Ahmadzai et al in 2013 (51) discuss three possible methods of calculating a dilution factor, none of which has established itself as a gold standard and none of which were used in the studies comprising this review. Only one study (30) used a dilution factor, giving their results in both $\mathrm{pg} / \mathrm{ml}$ and parts per million of palmitic acid. It remains to be seen whether this improves reproducibility. 
It has been suggested that lyophilisation may be useful for reducing variability by concentrating samples thereby raising biomarkers away from the lower end of assay sensitivity. There are a lack of studies examining the reliability and reproducibility of this method (51). Unfortunately the only studies in this review to have used this approach (Battaglia et al (20) and Sood et al (19)) concentrated their samples to differing levels (threefold and fourteenfold respectively). Furthermore, Sood et al reported an intra-assay CV of $37.7 \%$ and an inter-day CV of $71.6 \%$ when using this method.

The validity of any assessment of diagnostic test accuracy rests upon the accuracy of the reference standard to which it is compared; we included studies where diagnosis was conducted according to recognised guidelines.

A large number of exclusions were due to lack of diagnostic clarity; many undertook spirometry as a study measure rather than a diagnostic assessment and - unless reviewed by a physician and judged against a clearly described standard - can't be accepted as diagnostic confirmation. Furthermore, guidelines stress the importance of variable airflow obstruction to diagnosis; this cannot be assessed by a single spirometry measurement thereby complicating the process for any study wishing to have a rigorous diagnosis as the basis for inclusion.

Of concern were studies where it was neither explicitly stated that smokers were excluded, nor was smoking status featured in the participant description. There were six studies in which this occurred and over which there must be some concern that data might include that from smoking participants. This would be a potential confounder; there is evidence that EBC 8-isoprostane is significantly higher in smokers compared to healthy controls (52) and may increase in an acute smoking response (53).

Another potential confounder is the effect of food and drink; sixteen of the studies did not mention fasting prior to tests. The ATS/ERS guidelines (12) state that eating and drinking do not affect the non-volatile components of EBC as far as is known, but Ahmadzai (51) point out that food \& drink may elevate levels of oxidants in body fluids and has the potential to influence oxidant concentrations in EBC (although they identify no studies describing any such effect on 8-isoprostane). The extent to which this might constitute a confounder is unknown.

Several authors confirmed they were unable to measure 8-isoprostane in a majority of their samples (54-56). Of those studies in this review which reported undetectable samples the percentage ranged from $16 \%$ (Komakula et al) to 50\% (Piotrowski et al). Not all papers made clear the cause of missing data (whether an inability to obtain EBC samples or an inability to detect 8-isoprostane) nor how this was handled in the analysis. Gratziou et al (38) gave non-detectable levels of 8 -isoprostane a value of $3.9 \mathrm{pg} / \mathrm{ml}$ (the lower limit of 
assay detection) while Sood et al ascribed undetectable levels a value half the lower detection limit; neither state how many cases this applied to. If these samples came predominantly from healthy controls, raising them might obfuscate any difference between asthma and controls.

The absence of oxidative stress is a potential explanation of inability to detect 8isoprostane. This might be the case for studies of mild or intermittent asthma. The use of provocation tests or the study of moderate-to-severe asthma is one potential approach to this problem but the results of such studies were no less conflicted.

Although not one of our primary objectives we examined those factors for which an association with 8-isoprostane was reported. The majority of studies which assessed GORD and BMI reported a significant association with 8-isoprostane. It is possible that these are important confounders which may need to be controlled for in future studies.

\section{Limitations}

By employing rigorous inclusion criteria for asthma diagnosis and EBC methodology several 'key' papers were excluded, including that of Montuschi et al (46) frequently cited by others as justification for their methodology. We believe these exclusions were justified; the use of rigorous inclusion criteria are crucial for a review of diagnostic test accuracy.

Inability to assess the risk of bias in key domains of the QUADAS-2 quality assessment tool makes any conclusions from this review necessarily tentative. Furthermore, we were able to conduct meta-analysis of only four studies due to the frequent use of median, range, and log-transformed data.

The increasing ability to examine several biomarkers - for example Sedlak et al $(45,47)$ - creates a risk that non-significant findings may go unreported unless high reporting standards are adhered to. Hussain et al mention EBC 8-isoprostane in the methods section of a conference abstract (57) but not in the results, nor anywhere in the full published paper (58); suggesting that 8-isoprostane was either undetectable or the results were non-significant. Although these may constitute a publication bias, the underrepresentation of negative findings makes the lack of positive findings in this review more robust.

\section{Conclusion}

There is a trend towards higher EBC 8-isoprostane concentrations in subjects with asthma compared to controls. Twice as many studies reported higher levels amongst those with asthma than did not. However the strength of this evidence is weak and the number of studies reporting a significant difference was the same as that reporting none. A random 
effects meta-analysis found a significant difference between groups however its rigour is compromised by the small number of studies and substantial statistical heterogeneity.

Concentrating EBC samples may address some of the variability and difficulty arising from the use of ELISA. However, the central issue of calculating EBC dilution cuts across analytical methods and a gold standard is still to be determined. It will be essential to develop accurate, reliable and standardised methods of both EBC collection and 8isoprostane analysis if its use as a biomarker in asthma is to be properly evaluated.

\section{Appendix}

Table 1 - Search Terms

Terms relating to the condition of interest - Asthma* OR "Bronch* hyperreactivity" asthma

Terms relating to the collection method - "Exhaled breath condensate" OR "Breath test*" exhaled breath condensate. OR "Lung function test" OR "Expired air"

Terms relating to the biomarker of interest - *isoprostane* OR Dinoprost* OR * prost* OR

8-isoprostane

"Lipid peroxid*" OR *prostaglandin*

Master search string

(adapted for use in individual databases as

(Asthma* OR "Bronch* hyperreactivity") AND

("Exhaled breath condensate" OR "Breath test*"

required)

OR "Lung function test*" OR "Expired air") AND

(*isoprostane* OR Dinoprost* OR *prost* OR

"Lipid peroxid*" OR *prostaglandin*)

The strategy was modified as required for individual databases and the implemented in the following online databases: Cochrane, Embase, PubMed, Lilacs, Scopus,

ClinicalTrials.gov, Open Grey and ProQuest. 
Table 2 - Data Extraction Table

\begin{tabular}{|c|}
\hline Data extraction table \\
\hline $\begin{array}{l}\text { Study ID number, Authors, Year of publication, Country of study, Source / type of } \\
\text { publication }\end{array}$ \\
\hline Study design, Diagnostic criteria used, Time horizon, \\
\hline Sample size (total), number in control group, number in asthma group \\
\hline Average age in asthma group, Percentage female \\
\hline Average age of controls, Percentage female \\
\hline Character of asthma group (severity) \\
\hline Atopic status, Ethnicity, Intervention (e.g. allergen challenge, steroid therapy), \\
\hline $\begin{array}{l}\text { EBC collection Device, Methodological omissions, Method of EBC analysis, Units } \\
\text { used for 8-isoprostane }\end{array}$ \\
\hline $\begin{array}{l}\text { Average 8-isoprostane in control group (mean or median), Baseline 8-isoprostane } \\
\text { in asthma group (mean or median) }\end{array}$ \\
\hline $\begin{array}{l}\text { Average } 8 \text {-isoprostane after any intervention, average } 8 \text {-isoprostane in severity } \\
\text { groups (e.g. mild, moderate, severe), average } 8 \text {-isoprostane in steroid treated } \\
\text { group (baseline \& post-treatment), average } 8 \text {-isoprostane in steroid naïve patients } \\
\text { with asthma. }\end{array}$ \\
\hline $\begin{array}{l}\text { 8-isoprostane correlations with - FeNO, CO, pulmonary function (e.g. FEV1 or FVC } \\
\text { (\% predicted), sputum 8-isoprostane, plasma 8-isoprostane, serum inflammatory } \\
\text { markers (e.g. ESR, CRP). }\end{array}$ \\
\hline $\begin{array}{l}\text { 8-isoprostane correlations with - age, BMI, Cys-LTs, PGE2, results of methacholine } \\
\text { provocation test, interleukins (e.g. IL4, IL6), pH, sputum cell count, LTB4, urinary } \\
\text { markers, any other associations reported on (present or absent, positive or } \\
\text { negative) }\end{array}$ \\
\hline Reported \\
\hline
\end{tabular}


Table 3 - QUADAS-2 Assessment

\begin{tabular}{|c|c|c|c|c|c|c|c|}
\hline \multirow[t]{2}{*}{ Study } & \multicolumn{4}{|c|}{ RISK OF BIAS } & \multicolumn{3}{|c|}{ APPLICABILITY CONCERNS } \\
\hline & $\begin{array}{l}\text { PATIENT } \\
\text { SELECTION }\end{array}$ & $\begin{array}{l}\text { INDEX } \\
\text { TEST }\end{array}$ & $\begin{array}{l}\text { REFERENCE } \\
\text { STANDARD }\end{array}$ & $\begin{array}{l}\text { FLOW AND } \\
\text { TIMING }\end{array}$ & $\begin{array}{l}\text { PATIENT } \\
\text { SELECTION }\end{array}$ & $\begin{array}{l}\text { INDEX } \\
\text { TEST }\end{array}$ & $\begin{array}{l}\text { REFERENCE } \\
\text { STANDARD }\end{array}$ \\
\hline 1. Battaglia 2005 & $?$ & $?$ & (;) & (2) & (:) & (:) & (;) \\
\hline 2. Brussino 2010 & ? & ? & ;) & ;) & ;: & ;) & ;) \\
\hline 3. Carpagnano 2006 & (:) & $?$ & (:) & (:) & ;) & (:) & (:) \\
\hline 4. Fritscher 2012 & ? & ? & (:) & ? & (:) & (:) & ;: \\
\hline 5. Gratziou 2008 & $?$ & $?$ & (:) & ;) & ;) & (:) & (:) \\
\hline 6. Head 2013 & $?$ & $?$ & (:) & $\because$ & ? & (:) & (:) \\
\hline 7. Komakula 2007 & ? & $?$ & ;) & ;) & ;) & ;) & ;) \\
\hline 8. Kostikas 2002 & $?$ & $?$ & (:) & ;) & (:) & (:) & ;) \\
\hline 9. Mastalerz 2011 & $?$ & ? & (:) & (;) & (:) & (:) & (;) \\
\hline 10. Mastalerz 2015 & ? & $?$ & (:) & (:) & ? & (:) & (:) \\
\hline 11. Mickelborough 2013 & $?$ & $?$ & (:) & ? & $?$ & (:) & (:) \\
\hline 12. Piotrowski 2011 & ? & ? & (:) & (:) & (:) & (:) & (:) \\
\hline 13. Samitas 2009 & $?$ & $?$ & (:) & (:) & ? & (:) & (:) \\
\hline 14. Shimizu 2007 & $?$ & ? & (:) & ? & (:) & (:) & (;) \\
\hline 15. Sood 2013 & $?$ & (;) & (:) & $?$ & (:) & (:) & (;) \\
\hline 16. Zhao 2008 & ? & ? & (:) & ? & (;) & (:) & (:) \\
\hline
\end{tabular}

Potentially eligible studies

(conference abstracts)

\begin{tabular}{|c|c|c|c|c|c|c|c|c|}
\hline a. Gemicioglu 20 & 4 [conf. abstract] & ? & ? & (ن) & (ن) & (:) & ? & (:) \\
\hline b. Holguin 2009 & [review excerpt] & ? & ? & ? & ? & $(\dot{)}$ & ? & ? \\
\hline c. Sedlak 2013 & [conf. abstract] & ? & ? & ? & ? & ? & (:) & ? \\
\hline d. Sedlak 2012 & [conf. abstract] & ? & ? & ? & ? & ? & ? & ? \\
\hline
\end{tabular}

\footnotetext{
(:) = low risk / low level of concern regarding applicability

? = unclear risk / unclear level of concern regarding applicability

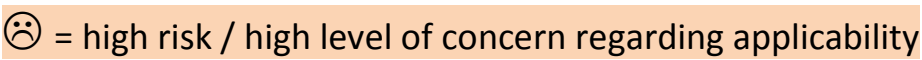




\section{Table 4 - GRADE Evidence Profile}

Setting: Adult non-smokers in any clinical setting.

Bibliography: Battaglia, Hertog, Timmers et al (2005); Brussino, Badiu, Sciascia et al (2010); Carpagnano, Resta, Ventura et al Gratziou, Rovina, Makris et al (2008); Komakula, Khatri, Mermis et al (2007); Kostikas, Papatheodorou, Ganas (2002); Piotrow Chorianopoulos, et al (2009); Shimizu, Dobashi, Zhao et al (2007); Sood, Qualls, Seagrave et al (2013); Zhao, Shimizu, Dobashi

\begin{tabular}{|c|c|c|c|c|c|c|c|}
\hline \multicolumn{7}{|c|}{ Quality assessment } & \multirow{2}{*}{ Imp } \\
\hline $\begin{array}{c}\text { № of } \\
\text { studies }\end{array}$ & Study design & $\begin{array}{c}\text { Risk of } \\
\text { bias }\end{array}$ & Inconsistency & Indirectness & Imprecision & Other considerations & \\
\hline \multicolumn{8}{|c|}{ Is exhaled breath condensate 8-isoprostane capable of differentiating between healthy controls and those with asthma? } \\
\hline 12 & $\begin{array}{l}\text { Mixture of } \\
\text { observational } \\
\text { and } \\
\text { experimental } \\
\text { studies }\end{array}$ & $\begin{array}{l}\text { Not } \\
\text { serious }\end{array}$ & Very serious $^{1}$ & Not serious & $\begin{array}{l}\text { Very } \\
\text { serious }{ }^{2}\end{array}$ & $\begin{array}{l}\text { Publication bias strongly } \\
\text { suspected; } \\
\text { all plausible residual confounding } \\
\text { would reduce the demonstrated } \\
\text { effect }^{3}\end{array}$ & Cases (asthma) 353; c \\
\hline
\end{tabular}

1. Significant unexplained variability in results; I-squared test for statistical heterogeneity $=94$

2. Large variance in study data

3. Probable publication bias

\section{GRADE Working Group grades of evidence}

High quality: We are very confident that the true effect lies close to that of the estimate of the effect

Moderate quality: We are moderately confident in the effect estimate: The true effect is likely to be close to the estimate of substantially different

Low quality: Our confidence in the effect estimate is limited: The true effect may be substantially different from the estimat Very low quality: We have very little confidence in the effect estimate: The true effect is likely to be substantially different $\mathrm{fr}$ 
Author

Average EBC 8-isoprostane

\begin{tabular}{|c|c|c|c|c|}
\hline & & & & \\
\hline & $\begin{array}{c}\text { Units } \\
\text { (measure of } \\
\text { central tendency) }\end{array}$ & $\begin{array}{l}\text { Measure of } \\
\text { variance }\end{array}$ & $\begin{array}{c}\text { Asthma } \\
\text { (variance) }\end{array}$ & $\begin{array}{c}\text { Control } \\
\text { (variance) }\end{array}$ \\
\hline $\begin{array}{l}\text { Battaglia, Hertog, } \\
\text { Timmers et al }\end{array}$ & $\begin{array}{c}\mathrm{pg} / \mathrm{ml} \\
\text { (median) }\end{array}$ & Range & $\begin{array}{c}2.10 \\
(1.6-2.7)\end{array}$ & $\begin{array}{c}3.6 \\
(2.9-7.6)\end{array}$ \\
\hline $\begin{array}{l}\text { Brussino, Badiu, Sciascia } \\
\text { et al }{ }^{*}\end{array}$ & $\begin{array}{c}\mathrm{pg} / \mathrm{ml} \\
\text { (geometrical mean) }\end{array}$ & $\begin{array}{l}\text { 95\% confidence } \\
\text { interval }\end{array}$ & $\begin{array}{c}21.56 \\
(19.92-23.35)\end{array}$ & $\begin{array}{c}16.43 \\
(15.50-17.41)\end{array}$ \\
\hline $\begin{array}{l}\text { Carpagnano, Resta, } \\
\text { Ventura et al }\end{array}$ & $\begin{array}{c}\mathrm{pg} / \mathrm{ml} \\
\text { (median) }\end{array}$ & Range & $\begin{array}{c}17.90 \\
(8.9-23.8)\end{array}$ & $\begin{array}{c}6.9 \\
(5.6-9.7)\end{array}$ \\
\hline $\begin{array}{l}\text { Fritscher, Post, Rodrigues } \\
\text { et al }\end{array}$ & $\begin{array}{c}\mathrm{pg} / \mathrm{ml} \\
\text { (median) }\end{array}$ & Range & $\begin{array}{c}0.60 \\
(0.4-2.0)\end{array}$ & $\begin{array}{c}0.9 \\
(0.2-1.7)\end{array}$ \\
\hline $\begin{array}{l}\text { Gratziou, Rovina, Makris } \\
\text { et al }\end{array}$ & $\begin{array}{c}\mathrm{pg} / \mathrm{ml} \\
\text { (median) }\end{array}$ & Interquartile range & $\begin{array}{c}39.0 \\
(4.0-125)\end{array}$ & $\begin{array}{c}18.5 \\
(4-37)\end{array}$ \\
\hline Head \& Mickleborough & $\begin{array}{c}\mathrm{pg} / \mu \mathrm{l} \\
\text { (mean) }\end{array}$ & Standard error & $\begin{array}{c}3.08 \\
(+/-1.5)\end{array}$ & - \\
\hline $\begin{array}{l}\text { Komakula, Khatri, Mermis } \\
\text { et al }\end{array}$ & $\begin{array}{l}\mathrm{pg} / \mathrm{ml} \\
\text { (mean) }\end{array}$ & $95 \% \mathrm{Cl}$ & $\begin{array}{c}11.0 \\
(9.6-12.4)\end{array}$ & $\begin{array}{c}11.0 \\
(8.0-13.8)\end{array}$ \\
\hline $\begin{array}{l}\text { Kostikas, Papatheodorou, } \\
\text { Ganas }\end{array}$ & $\begin{array}{l}\mathrm{pg} / \mathrm{ml} \\
\text { (mean) }\end{array}$ & Standard deviation & $\begin{array}{l}33.0 \\
(11)\end{array}$ & $\begin{array}{l}20.0 \\
(7)\end{array}$ \\
\hline $\begin{array}{l}\text { Mastalerz, Sanak, Kumik } \\
\text { et al }\end{array}$ & $\begin{array}{l}\mathrm{pg} / \mathrm{ml} \\
\text { (mean) }\end{array}$ & Standard deviation & $\begin{array}{c}0.25 \\
(+/-0.12)\end{array}$ & - \\
\hline $\begin{array}{l}\text { Mastalerz, Januszek, } \\
\text { Kaszuba et al } \\
\text { AERD } \\
\quad \&\end{array}$ & $\begin{array}{c}\mathrm{pg} / \mathrm{ml} \\
\text { (median) }\end{array}$ & Interquartile range & $\begin{array}{c}0.28 \\
(0.19-0.49)\end{array}$ & - \\
\hline $\begin{array}{l}\quad \text { ATA } \\
\text { (two asthma groups } \\
\text { within study) }\end{array}$ & & & $\begin{array}{c}0.54 \\
(0.35-1.65)\end{array}$ & - \\
\hline $\begin{array}{l}\text { Mickleborough, Vaughn, } \\
\text { Shei et al }\end{array}$ & $\begin{array}{l}\mathrm{pg} / \mathrm{ml} \\
\text { (mean) }\end{array}$ & Standard deviation & $\begin{array}{c}46.40 \\
(+/-15.1)\end{array}$ & - \\
\hline $\begin{array}{l}\text { Piotrowski, Majewski, } \\
\text { Marczak et al } \\
\text { Severe asthma } \\
\text { \& }\end{array}$ & $\begin{array}{c}\mathrm{pg} / \mathrm{ml} \\
\text { (median) }\end{array}$ & Interquartile range & $\begin{array}{c}3.8 \\
(2.5-10.73)\end{array}$ & $\begin{array}{c}6.93 \\
(2.5-12.98)\end{array}$ \\
\hline $\begin{array}{l}\text { Never treated asthma } \\
\text { (two groups within study) }\end{array}$ & & & $\begin{array}{c}4.67 \\
(2.5-27.92)\end{array}$ & \\
\hline $\begin{array}{l}\text { Samitas, Chorianopoulos, } \\
\text { et al }\end{array}$ & $\begin{array}{l}\mathrm{pg} / \mathrm{ml} \\
\text { (mean) }\end{array}$ & Standard error & $\begin{array}{l}59.30 \\
(+/-4)\end{array}$ & $\begin{array}{c}16.4 \\
(+/-1.6)\end{array}$ \\
\hline $\begin{array}{l}\text { Shimizu, Dobashi, Zhao et } \\
\text { al }\end{array}$ & $\begin{array}{l}\mathrm{pg} / \mathrm{ml} \\
\text { (mean) }\end{array}$ & Standard error & $\begin{array}{c}27.70 \\
(+/-2.3)\end{array}$ & $\begin{array}{c}6.6 \\
(+/-1.2)\end{array}$ \\
\hline $\begin{array}{l}\text { Sood, Qualls, Seagrave et } \\
\text { al }^{*}\end{array}$ & $\begin{array}{l}\mathrm{pg} / \mathrm{ml} \\
\text { (mean) }\end{array}$ & Standard deviation & $\begin{array}{c}2.50 \\
(+/-0.99)\end{array}$ & $\begin{array}{c}1.54 \\
(+/-1.39)\end{array}$ \\
\hline $\begin{array}{l}\text { Zhao, Shimizu, Dobashi et } \\
\text { al }\end{array}$ & $\begin{array}{c}\mathrm{pg} / \mathrm{ml} \\
\text { (median) }\end{array}$ & Interquartile range & $\begin{array}{c}16.20 \\
(11.7-19.1)\end{array}$ & $\begin{array}{c}3.5 \\
(2.6-7.9)\end{array}$ \\
\hline
\end{tabular}

${ }^{*}$ Log transformed data 
Potentially eligible studies

(conference abstracts)

Gemicioglu, Duman,

Akdeniz et al

No units given (mean)

$\mathrm{pg} / \mathrm{ml}$

(mean)

Sedlak, Cap, Kacer et al

No units given

(?)

Sedlak, Cap, Kacer et al $\mathrm{pg} / \mathrm{ml}$

(?)
Standard deviation 95\% confidence interval No measure of variance given No measure of variance given
135.72

(+/- 38.85)

Unable to extract data Result not directly cited

78.10

Table 6 - Sub-Group Analysis: Moderate or Severe asthma

\section{8-isoprostane concentration levels}

\section{Asthma > controls}

All papers

Conference

abstracts removed
5 studies

$(n=253)$

3 studies

$(n=174)$
Controls $\geq$ asthma

3 studies

$(n=273)$

2 studies

$(n=166)$ 


\section{References}

1. Sidorenko GI, Zborovskii El, Levina DI. [Surface-active properties of the exhaled air condensate (a new method of studying lung function)]. Terapevticheskii arkhiv. 1980;52(3):65-8.

2. Rahman I, Morrison D, Donaldson K, Macnee W. Systemic oxidative stress in asthma, COPD, and smokers. American Journal of Respiratory and Critical Care Medicine. 1996;154(4 I):1055-60.

3. Cho YS, Moon H-B. The role of oxidative stress in the pathogenesis of asthma. Allergy Asthma Immunol Res. 2010;2(3):183-7.

4. ben Anes A, Fetoui H, Bchir S, ben Nasr H, Chahdoura H, Chabchoub E, et al. Increased oxidative stress and altered levels of nitric oxide and peroxynitrite in Tunisian patients with chronic obstructive pulmonary disease: correlation with disease severity and airflow obstruction. Biological Trace Element Research. 2014;161(1):20-31. 5. Bowler RP, Crapo JD. Oxidative stress in allergic respiratory diseases. The Journal of allergy and clinical immunology. 2002;110(3):349-56.

6. Roberts $2 \mathrm{nd} \mathrm{L}$, Morrow J. The isoprostanes: novel markers of lipid peroxidation and potential mediators of oxidant injury. Advances in prostaglandin, thromboxane, and leukotriene research. 1995;23:219.

7. Montuschi P, Kharitonov SA, Ciabattoni G, Corradi M, van Rensen L, Geddes DM, et al. Exhaled 8-isoprostane as a new non-invasive biomarker of oxidative stress in cystic fibrosis. Thorax. 2000;55(3):205-9.

8. Montuschi P, Barnes PJ, Roberts L. Isoprostanes: markers and mediators of oxidative stress. The FASEB Journal. 2004;18(15):1791-800.

9. Thomas PS, Lowe aJ, Samarasinghe $\mathrm{P}$, Lodge $\mathrm{CJ}$, Huang $\mathrm{Y}$, Abramson MJ, et al. Exhaled breath condensate in pediatric asthma: Promising new advance or pouring cold water on a lot of hot air? A systematic review. Pediatric Pulmonology. 2013;48(5):419-42.

10. Cruz MJ, Sanchez-Vidaurre S, Romero PV, Morell F, Munoz X. Impact of age on pH, 8-isoprostane, and nitrogen oxides in exhaled breath condensate. Chest. 2009;135(2):462-7.

11. Horvath I, Hunt J, Barnes PJ. Exhaled breath condensate: methodological recommendations and unresolved questions. The European respiratory journal. 2005;26.

12. Horváth I, Hunt J, Barnes PJ. Exhaled breath condensate: methodological recommendations and unresolved questions. European Respiratory Journal. 2005;26(3):523-48.

13. Vass G, Huszár É, Barát E, Valyon M, Kiss D, Pénzes I, et al. Comparison of Nasal and Oral Inhalation during Exhaled Breath Condensate Collection. American Journal of Respiratory and Critical Care Medicine. 2003;167(6):8505.

14. Corp. I. IBM SPSS Statistics for Windows,. Version 230 Armonk, NY: IBM Corp. 2015.

15. Whiting PF, Rutjes AW, Westwood ME, Mallett S, Deeks JJ, Reitsma JB, et al. QUADAS-2: a revised tool for the quality assessment of diagnostic accuracy studies. Annals of internal medicine. 2011;155(8):529-36.

16. Schünemann HJ, Oxman AD, Brozek J, Glasziou P, Jaeschke R, Vist GE, et al. Grading quality of evidence and strength of recommendations for diagnostic tests and strategies. BMJ. 2008;336(7653):1106-10.

17. Guyatt GH, Oxman AD, Vist GE, Kunz R, Falck-Ytter Y, Alonso-Coello P, et al. GRADE: an emerging consensus on rating quality of evidence and strength of recommendations. BMJ. 2008;336(7650):924-6.

18. Samitas K, Chorianopoulos D, Vittorakis S, Zervas E, Economidou E, Papatheodorou G, et al. Exhaled cysteinyl-leukotrienes and 8-isoprostane in patients with asthma and their relation to clinical severity. Respiratory medicine. 2009;103(5):750-6.

19. Sood A, Qualls C, Seagrave J, McDonald J, Shohreh R, Chiavaroli A, et al. Effect of allergen inhalation on airway oxidant stress, using exhaled breath condensate 8-isoprostane, in mild asthma. Journal of Asthma. 2013;50(5):449-56.

20. Battaglia S, Den Hertog H, Timmers M, Lazeroms S, Vignola A, Rabe K, et al. Small airways function and molecular markers in exhaled air in mild asthma. Thorax. 2005;60(8):639-44.

21. Fritscher LG, Post M, Rodrigues MT, Silverman F, Balter M, Chapman KR, et al. Profile of eicosanoids in breath condensate in asthma and COPD. Journal of breath research. 2012;6(2):026001.

22. Kostikas K, Papatheodorou G, Ganas K, Psathakis K, Panagou P, Loukides S. pH in expired breath condensate of patients with inflammatory airway diseases. American Journal of Respiratory and Critical Care Medicine.

2002;165(10):1364-70.

23. Soyer O, Dizdar E, Keskin O, Lilly C, Kalayci O. Comparison of two methods for exhaled breath condensate collection. Allergy. 2006;61(8):1016-8. 
24. Czebe K, Barta I, Antus B, Valyon M, Horvath I, Kullmann T. Influence of condensing equipment and temperature on exhaled breath condensate $\mathrm{pH}$, total protein and leukotriene concentrations. Respiratory medicine. 2008;102(5):720-5.

25. Rosias PP, Robroeks CM, Niemarkt HJ, Kester AD, Vernooy JH, Suykerbuyk J, et al. Breath condenser coatings affect measurement of biomarkers in exhaled breath condensate. European Respiratory Journal. 2006;28(5):103641.

26. Chemical C. 8-isoprostane Elisa Kit. 2015.

27. II'yasova D, Morrow JD, Ivanova A, Wagenknecht LE. Epidemiological marker for oxidant status: comparison of the ELISA and the gas chromatography/mass spectrometry assay for urine 2, 3-dinor-5, 6-dihydro-15-F 2tisoprostane. Annals of epidemiology. 2004;14(10):793-7.

28. Sircar D, Subbaiah PV. Isoprostane measurement in plasma and urine by liquid chromatography-mass spectrometry with one-step sample preparation. Clinical chemistry. 2007;53(2):251-8.

29. Kadiiska M, Gladen B, Baird D, Germolec D, Graham L, Parker C, et al. Biomarkers of oxidative stress study II: are oxidation products of lipids, proteins, and DNA markers of $\mathrm{CCl} 4$ poisoning? Free Radical Biology and Medicine. 2005;38(6):698-710.

30. Mastalerz L, Sanak M, Kumik J, Gawlewicz-Mroczka A, Celejewska-Wojcik N, Ćmiel A, et al. Exhaled eicosanoids following bronchial aspirin challenge in asthma patients with and without aspirin hypersensitivity: the pilot study. Journal of allergy. 2012;2012.

31. McMaster University (developed by Evidence Prime I. GRADEpro GDT: GRADEpro Guideline Development Tool 2015.

32. Wallace BC, Dahabreh IJ, Trikalinos TA, Lau J, Trow P, Schmid CH. Closing the Gap between Methodologists and End-Users: R as a Computational Back-End. Journal of Statistical Software. 2012;49(5):1-15.

33. Zhao J, Shimizu Y, Dobashi K, Kawata T, Ono A, Yanagitani N, et al. The relationship between oxidative stress and acid stress in adult patients with mild asthma. Journal of Investigational Allergology and Clinical Immunology. 2008;18(1):41.

34. Carpagnano G, Resta O, Ventura M, Amoruso A, Gioia G, Giliberti T, et al. Airway inflammation in subjects with gastro - oesophageal reflux and gastro - oesophageal reflux - related asthma. Journal of internal medicine. 2006;259(3):323-31.

35. Piotrowski WJ, Majewski S, Marczak J, Kurmanowska Z, Gorski P, Antczak A. Exhaled breath 8-isoprostane as a marker of asthma severity. Archives of medical science : AMS. 2012;8(3):515-20.

36. Kostikas K, Papaioannou Al, Tanou K, Giouleka P, Koutsokera A, Minas M, et al. Exhaled NO and exhaled breath condensate $\mathrm{pH}$ in the evaluation of asthma control. Respiratory medicine. 2011;105(4):526-32.

37. Brussino L, Badiu I, Sciascia S, Bugiani M, Heffler E, Guida G, et al. Oxidative stress and airway inflammation after allergen challenge evaluated by exhaled breath condensate analysis. Clinical \& Experimental Allergy. 2010;40(11):1642-7.

38. Gratziou C, Rovina N, Makris M, Simoes D, Papapetropoulos A, Roussos C. Breath markers of oxidative stress and airway inflammation in seasonal allergic rhinitis. International journal of immunopathology and pharmacology. 2008;21(4):949-57.

39. Mastalerz L, Januszek R, Kaszuba M, Wójcik K, Celejewska-Wójcik N, Gielicz A, et al. Aspirin provocation increases 8-iso-PGE 2 in exhaled breath condensate of aspirin-hypersensitive asthmatics. Prostaglandins \& other lipid mediators. 2015;121:163-9.

40. Tufvesson E, Bjermer L. Methodological improvements for measuring eicosanoids and cytokines in exhaled breath condensate. Respiratory medicine. 2006;100(1):34-8.

41. Davidsson A, Schmekel B. Efficacy of two breath condensers. Journal of clinical laboratory analysis. 2010;24(4):219-23.

42. Prieto L, Ferrer A, Palop J, Domenech J, Llusar R, Rojas R. Differences in exhaled breath condensate pH measurements between samples obtained with two commercial devices. Respiratory medicine. 2007;101(8):1715-

20.

43. Goldoni M, Caglieri A, Andreoli R, Poli D, Manini P, Vettori MV, et al. Influence of condensation temperature on selected exhaled breath parameters. BMC Pulmonary Medicine. 2005;5(1):1.

44. Koczulla R, Dragonieri S, Schot R, Bals R, Gauw SA, Vogelmeier C, et al. Comparison of exhaled breath condensate $\mathrm{pH}$ using two commercially available devices in healthy controls, asthma and COPD patients. Respiratory research. 2009;10(1):1-8. 
45. Sedlák V, Cáp P, Kacer P, Malý M, VIcková Š, Pelclová D. Influence of oral steroid use in difficult-to-control asthma patients on metabolomic profile of oxidative stress in exhaled breath condensate (EXAIR project). European Respiratory Journal. 2012;40(Suppl 56):P311.

46. Montuschi P, Corradi M, Ciabattoni G, Nightingale J, Kharitonov Sa, Barnes PJ. Increased 8-isoprostane, a marker of oxidative stress, in exhaled condensate of asthma patients. American Journal of Respiratory and Critical Care Medicine. 1999;160(1):216-20.

47. Sedlák V, Cáp P, Kacer P, Kuzma M, Pelclova D. Influence of inflammatory phenotype in severe refractory asthma on metabolomic profile of oxidative stress in exhaled breath condensate (EBC). European Respiratory Journal. 2013;42(Suppl 57):P3553.

48. Komakula S, Khatri S, Mermis J, Savill S, Haque S, Rojas M, et al. Body mass index is associated with reduced exhaled nitric oxide and higher exhaled 8-isoprostanes in asthmatics. Respir Res. 2007;8:32.

49. Holguin F, Fitzpatrick A. Obesity, asthma, and oxidative stress. Journal of Applied Physiology. 2010;108(3):754-9.

50. Shimizu Y, Dobashi K, Zhao JJ, Kawata T, Ono A, Yanagitani N, et al. Proton pump inhibitor improves breath marker in moderate asthma with gastroesophageal reflux disease. Respiration. 2007;74(5):558-64.

51. Ahmadzai H, Huang S, Hettiarachchi R, Lin J-L, Thomas PS, Zhang Q. Exhaled breath condensate: a comprehensive update. Clinical Chemistry And Laboratory Medicine: CCLM / FESCC. 2013;51(7):1343-61.

52. Inonu H, Doruk S, Sahin S, Erkorkmaz U, Celik D, Celikel S, et al. Oxidative stress levels in exhaled breath condensate associated with COPD and smoking. Respiratory care. 2012;57(3):413-9.

53. Montuschi P, Collins JV, Ciabattoni G, Lazzeri N, Corradi M, Kharitonov SA, et al. Exhaled 8-isoprostane as an in vivo biomarker of lung oxidative stress in patients with COPD and healthy smokers. Am J Respir Crit Care Med. 2000;162(3 Pt 1):1175-7.

54. Simpson J, Wood L, Gibson P. Inflammatory mediators in exhaled breath, induced sputum and saliva. Clinical \& Experimental Allergy. 2005;35(9):1180-5.

55. Sathyamurthy R, Manney S, Webster C, Krishna T, Perkins G, Mansur A. P3 Oxidative Distress and Antioxidants in Severe Asthma. Thorax. 2012;67(Suppl 2):A65-A.

56. Bartova S, Kuzma M, Sedlak V, Cap P, Kacer P, Pelclova D, et al., editors. Effect of corticosteroids on metabolomic profile of exhaled breath condensate in patients suffering from difficult-to-control asthma: use of LCMS/MS and NMR metabolomics. FEBS JOURNAL; 2012: WILEY-BLACKWELL 111 RIVER ST, HOBOKEN 07030-5774, NJ USA.

57. Hussain S, Coleman J, Koganti M, Youseff H, Ebert O, Li S, et al. Diesel Exposure In Mild And Moderate Asthmatics: Effects Of Oxidative Stress. Medicine. 2010;4:5.

58. Hussain S, Laumbach R, Coleman J, Youseff H, Kelly-McNeil K, Ohman-Strickland P, et al. Controlled Exposure to Diesel Exhaust Causes Increased Nitrite in Exhaled Breath Condensate among Subjects with Asthma. Journal of occupational and environmental medicine / American College of Occupational and Environmental Medicine. 2012;54(10):1186-91. 